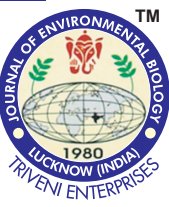

\title{
Assessment of salinity tolerance based upon morpho-physiological attributes in white jute (Corchorus capsularis L.)
}

\begin{tabular}{lll}
\hline Paper received: 24.04.2018 Revised received: 03.08.2018 Re-revised received: $22.09 .2018 \quad$ Accepted: 09.11 .2018 \\
\hline
\end{tabular}

\section{Authors Info \\ M. Ramesh Naik, D. Barman', R.T. Maruthi', V.R. Babu', U.K. Mandal ${ }^{2}$ and D.K. Kundu ${ }^{1}$ \\ ${ }^{1}$ ICAR-Central Research Institute for Jute and Allied Fibres, Barrackpore-700 120, India ${ }^{2}$ ICAR-Central Soil Salinity Research Institute, Regional Research Station, \\ Canning Town-743 329, India \\ *Corresponding Author Email : rameshag16@gmail.com}

\section{Edited by \\ Dr. C.S. Kar}

\section{Reviewed by}

Dr. Ajay Kumar

Dr. R.B. Raizada
Abstract

Aim : Astudy was conducted to evaluate the salinity tolerance of white jute (C. capsularis) cultivars.

Methodology : Five white jute cultivars were assessed for differen salinity concentrations $(0,100,150$, 200 and $250 \mathrm{mM} \mathrm{NaCl}$ ) in a split plot design with three replications per concentration under greenhouse condition. A total of fifteen plants were sampled from each treatment ten days after treatment with $\mathrm{NaCl}$ to determine morphological and physiological parameters.

Results : Increased $\mathrm{NaCl}$ concentrations reduced all the morphological and physiological parameters such as plant height, root length, number of leaves, leaf area, shoot and root dry weight, relative leaf water content (RLWC), chlorophyll, protein, proline content, $\mathrm{K}^{+}$accumulation in shoot and leaves but water saturation deficit (WSD) and $\mathrm{Na}^{+}$contents were increased in the shoot and leaves.

Interpretation : The study revealed that among all cultivars assessed JRC-532 and JRC-321 showed relatively better performance against salt stress whereas cultivar JRC-517 was found more susceptible to salt stress.

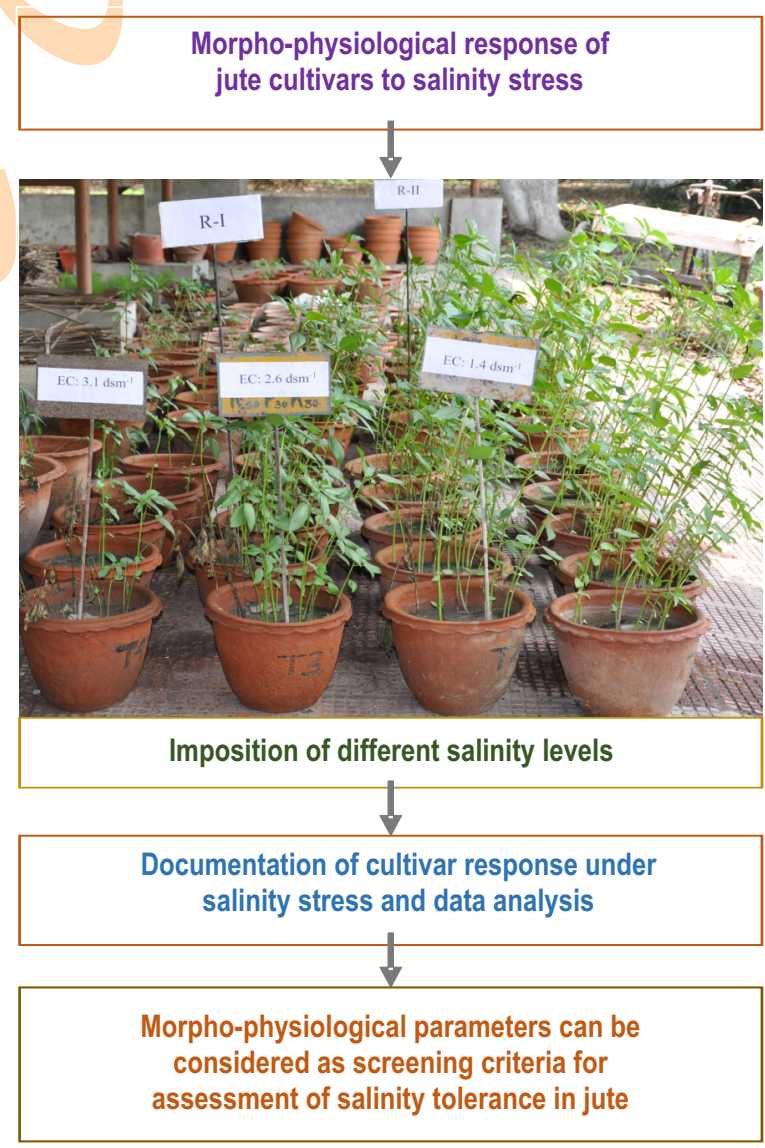

Key words: Chlorophyll, Corchorus capsularis, Proline, Relative water content, Water saturation deficit

How to cite : Ramesh Naik, M., D. Barman, R.T. Maruthi, V.R. Babu, U.K. Mandal and D.K. Kundu: Assessment of salinity tolerance based upon morphophysiological attributes in white jute (Corchorus capsularis L.). J. Environ. Biol., 40, 377-383 (2019). 


\section{Introduction}

Traditionally, jute is an important bast fibre (phloem) producing cash crop, which belongs to family Malvaceae and genus Corchorus. The genus Corchorus consists of around 100 species (Saunders, 2001). However, only two species viz. Corchorus capsularis L. (Desi/ white jute) and Corchorus olitorius $\mathrm{L}$. (tossa jute) are grown commercially in tropical and subtropical regions. This cash crop is the source of versatile eco-friendly natural fibre, and is second next to cotton in terms of production and diversified value added products and uses (Islam et al., 2013). Apart from fibre, ideally tender leaves from young jute plants, owing to high proteins, vitamins $(A, C, E)$ and mineral nutrients like calcium and iron, are consumed as a green leafy vegetable in rural belts of Asian, African and European countries (Steyn et al., 2001; Dansi et al., 2008; Choudhary et al., 2013).

Salt stress is one amongst the major abiotic factor limiting jute cultivation in India and Bangladesh. In India, total salt affected soils is 6.7 million ha, out of which 1.47 million ha which constitute both 0.75 million ha of salinity/white alkali soil and 0.72 million ha sodic soil is occupied by jute cultivating states (Mandal et al., 2010). Moreover, recent cyclone like Aila in India and Bangladesh has converted vast non-saline crop lands to salt affected areas and this salinity developed in soils is still increasing day by day due to raise in sea level per se consequence of global warming (www.savebd.com).

Salinity stress impacts plant physiology by affecting both water relations (water stress) and ionic relations (ionic stress). During the initial exposure to salinity stress, it affects the water relations in the plant, ultimately inhibiting leaf expansion (Munns and Termaat, 1986). While in the later phase chronic exposure to salinity inflicts the mounting up of ions $\left(\mathrm{Na}^{+}\right.$and $\mathrm{Cl}$ ) within the shoot to lethal concentrations whereby uptake of essentia nutrients is hindered. The ionic stress is localized to older leaves, causing premature senescence and ultimately leads to reduced yield or plant death (Munns and Tester, 2008).

In order to retaliate with the stress affect, salt tolerant plants have the ability to attenuate these pre-judicious affects by producing a series of anatomical, morphological and physiological adaptations (Hameed and Ashraf, 2008). Munns and Tester (2008) proposed three main salinity tolerance mechanisms: ion exclusion, tissue tolerance and shoot ionindependent tolerance. Other physiological mechanisms contributing to salinity tolerance include biosynthesis of amino acids, sugars, hormones and utilization of these compounds to regulate osmotic pressure. Among the amino acids, proline plays an important role in osmotic adjustment of plant's cells. The production of antioxidants (Ashraf, 2009) and early seedling growth (Kingsbury and Epstein, 1984) are also the mechanisms developed by salt tolerant plants. Recently, it has been reported that jute can grow readily in saline soils (Hongya et al., 2011). Screening of jute cultivars tolerant to salinity can bring up nonarable saline soils of Indo-Gangetic plains under jute cultivation, endorsing enhanced fibre production coupled with meeting the nutritional requirement of masses in coastal areas. Therefore, high yielding salinity tolerant jute cultivars either to be screened from the pre-existing cultivars or breeding of new cultivars is necessitated. However, screening for salt tolerance under field condition is often not feasible owing to heterogeneous nature of soil and seasonal fluctuation in rainfall (Akram et al., 2010). In fact, evaluation of salinity tolerance of jute at seedling stage under greenhouse condition is considered a suitable and efficient approach for generating information on the prevalence and nature of salt tolerance jute. Seed germination and seedling growth are two crucial and vulnerable stages in the early life cycle of terrestrial angiosperms in regards to salinity stress. The relative reduction in seed germination and growth have earlier been used for assessing salt tolerance of jute in China (Ma et al., 2011) and for C. capsularis in India (Naik et al., 2015). Hence, the present investigation was undertaken to assess the tolerance of different high yielding white jute (C. capsularis) cultivars towards salinity sterss.

\section{Materials and Methods}

Plant material and screening protocols: The experiment was carried out with five white jute (C. capsularis) cultivars namely, JRC-698 (Multi-cross involving 13 parents), JBC-5 (JRC-321 x THA/Y/086C), JRC-532 (CHN/FJ/044C x JRC-321), JRC-321 (selection from 'Hewti') and JRC-517 (JRC-212 x JRC-4444) in the greenhouse of I.C.A.R.-Central Research Institute for Jute and Allied Fibres, Barrackpore, Kolkata, India. Each cultivar was replicated thrice to screen five concentrations of $\mathrm{NaCl}(0$, $100,150,200$ and $250 \mathrm{mM}$ ). Their response to salinity stress was measured in terms of morphological and physiological characteristics viz., root length, shoot length, dry weight of roots and shoots, relative water content in leaves, chlorophyll, protein, proline content in leaves, $\mathrm{Na}^{+}$and $\mathrm{K}^{+}$ion content in shoot and leaves. Earthen pots of $28 \mathrm{~cm} \times 30 \mathrm{~cm}$ with a capacity to hold 6-8 kg soil were used for the study. Fertilizer @ 80:40:40 kg N:P:K ha-1 was applied uniformly, based on weight of soil in each pot. Full dose (40:40 kg P:K ha-1) of $P$ and $K$ and half dose $\left(40 \mathrm{~kg} \mathrm{~N} \mathrm{ha}^{-1}\right)$ of $\mathrm{N}$ were applied as basal dose and top-dressed with remaining $\mathrm{N}$ dose at 35 days after sowing.

Prior to sowing, soil samples were collected to assess the initial chemical parameters such as soil pH: 6.5 , electrical conductivity: $0.6 \mathrm{dsm}^{-1}$, soil organic carbon $(0.61 \%)$, available nitrogen (313.6 kg ha-1), phosphorous (39.3 kg ha-1) and potassium $\left(180 \mathrm{~kg} \mathrm{ha}^{-1}\right)$. Post emergence of true leaves and roots (20 days after sowing), the number of plants per pot was limited to ten. Test concentrations of $\mathrm{NaCl}(0,100,150,200$ and $250 \mathrm{mM})$ were imposed after 30 days of sowing, and normal water served as control (Ghoulam et al., 2002). Post imposition of $\mathrm{NaCl}$ test concentrations, soil electrical conductivity $\left(\mathrm{ds} \mathrm{m}^{-1}\right)$ and total dissolved solid $\left(\mathrm{mgl}^{-1}\right)$ were measured.

Morphological parameters: A total of fifteen plants was sampled from each treatment (five plants per replicate) 10 days after treatment with $\mathrm{NaCl}$, to determine the morphological and 
physiological parameters. Shoot and root length were measured by using metric scale, fresh biomass weight was recorded on an electronic precision balance and the samples were sun dried for $12 \mathrm{hrs}$ and later kept in a hot air oven at $65 \pm 2^{\circ} \mathrm{C}$ for 24 hrs to acquire their dry biomass weight. Basal diameter was measured by using Vernier callipers. Relative leaf water content (RLWC) of jute leaves was calculated by the formula given by Smart and Bingham (1974). The youngest fully expanded leaves from each plant were used for measuring RLWC. Water saturation deficit (WSD) was determined following the method of Weatherly and Slatyer (1957).

Physiological parameters: Chlorophyll content in fully expanded leaves was estimated by the method Hiscox and Israelstam (1979). Protein content was estimated following the method of Lowry et al. (1951). Inorganic ions ( $\mathrm{Na}^{+}$and $\left.\mathrm{K}^{+}\right)$were analyzed, from stem and leaf samples by tri-acid digestion method (Ghoulam et al., 2002). Free proline content in leaves was estimated by acid ninhydrin method (Bates et al., 1973).

Statistical analysis: For all parameters, data were analyzed by two-way analysis of variance (ANOVA) using STATISTICA program. The significance was tested at $5 \%$ level.

\section{Results and Discussion}

The experimental studies revealed that, $\mathrm{NaCl}$ caused a significant reduction in all the growth parameters examined among the five jute cultivars (Fig.1). Two-way ANOVA also showed a significant $(P<0.05)$ varietal consequence, except for root length parameter. Moreover, with increasing salinity concentration, reduction in growth parameters was higher across five cultivars studied. Salt stress generally makes agricultural crops fatal during the process of growth. Hence, it is crucially important for the establishment of the plants growing under such salt stress conditions.

The percent reduction in shoot length was found at 100 $\mathrm{mM} \mathrm{NaCl}$ but later on showed an increasing trend with elevated levels of salinity and perfect negative correlation with increasing levels of $\mathrm{NaCl}$. The percentage reduction in shoot length was greater at 200 and $250 \mathrm{mM} \mathrm{NaCl}$ and highest reduction was manifested in cultivars JRC-517, JRC-698 and $\mathrm{JBC}-5$ where it reached around $50 \%$ at $250 \mathrm{mM} \mathrm{NaCl}$. Reduction in shoot length is a common physiological response in plant under high salt concentrations and has been reported specifically for jute by Islam et al. (2011).

There were no significant differences between the cultivars in terms of root length, highest percentage of reduction (40\%) was depicted in cultivar JRC-517 at $250 \mathrm{mM} \mathrm{NaCl}$. The increasing trend in shoot and root length reduction percentage with increasing $\mathrm{NaCl}$ concentration revealed that root and shoot growth serves as an indicator of salt stress in jute crop. There have been numerous such reports of $\mathrm{NaCl}$ inhibiting root and shoot growth (Abass and Latif, 2005; Zhang et al., 2014; Hoque et al., 2015; Kotagiri and Kolluru, 2017) in plant. Number of leaves per plant was significantly affected due to salinity stress. Tested cultivars JRC-517 and JRC-698 documented greater than 70\% reduction in leaf number, and similar result were also reported by Odunnaike et al. (2013). The leaf area reduction was directly proportional to $\mathrm{NaCl}$ concentration. It was significantly less at lower concentrations of $\mathrm{NaCl}$, with increasing levels of $\mathrm{NaCl}$ stress the percentage of reduction also increased simultaneously and highest leaf area reduction of $65 \%$ was observed in cultivar JBC-5. Dry weight gradually decreased owing to stress in both shoots and roots, as reported in other studies (Islam et al., 2011). The reduction in dry weight were more pronounced at $200 \mathrm{mM}$ and $250 \mathrm{mM} \mathrm{NaCl}$, especially for the cultivar JRC-517, which attained $47 \%$ and $69 \%$ in comparison to dry weight of shoot and roots of control treatment. Shoot and root lengths do not always illustrate to shoot and root weights. In the present study, though few cultivars possessed long shoots and roots, thin and unbranched, ultimately derived no sufficient dry weight. For this reason, when the length and dry weight are considered as selection criteria, emphasis on dry weight is given prime importance.

Major photosynthetic pigments in higher plants are chlorophyll $a$ and chlorophyll $b$. Results demonstrated an inversely proportional trend where in increasing concentration of $\mathrm{NaCl}$ provoked reduction in the amount of leaf chlorophyll content as such. Among five tested cultivars, highest mean chlorophyll a $\left(2.08 \mathrm{mg} \mathrm{g}^{-1}\right)$, chlorophyll b $\left(0.67 \mathrm{mg} \mathrm{g}^{-1}\right)$ and total chlorophyll $(2.75$ $\mathrm{mg} \mathrm{g}^{-1}$ ) was recorded in JRC-532 and all these parameters was at par with cultivar JRC-321 (Table 1). While the lowest chlorophyll a (1.65 mg g $\left.{ }^{-1}\right)$, chlorophyll b (0.49 $\left.\mathrm{mg} \mathrm{g}^{-1}\right)$ and total chlorophyll (2.15 $\mathrm{mg} \mathrm{g}^{-1}$ ) was recorded in JRC-517. Interaction of $\mathrm{NaCl}$ and cultivars indicated that highest total chlorophyll content $(3.16 \mathrm{mg}$ $\mathrm{g}^{-1}$ ) was recorded for cultivar JRC-532 at $100 \mathrm{mM} \mathrm{NaCl}$ while the lowest total chlorophyll content $\left(1.54 \mathrm{mg} \mathrm{g}^{-1}\right)$ was found in JRC517 at $250 \mathrm{mM} \mathrm{NaCl}$. Ghosh et al. (2013) also reported that chlorophyll content decreased under high salinity condition perhaps due to increased inhibition of chlorophyll synthesis or disintegration of chloroplast.

The relative leaf water content gradually declined with increasing $\mathrm{NaCl}$ concentration. This is inconformity with previous studies of Chaudhuri and Choudauri (1997). There was no significance in the varietal response however, the relative change between the control (93\%) and high $\mathrm{NaCl}$ treatment $(250 \mathrm{Mm}$; $56 \%$ ) was more prominent in cV. JRC-517. The water uptake was more inhibited in cv. JRC-698 (61\%) at $250 \mathrm{mM} \mathrm{NaCl}$ in contrast to control $(82 \%)$. There was significant difference among the cultivars in relation to water saturation deficiency and was found highest in cV. JRC-698.

Among all the tested cultivars, $\mathrm{NaCl}$ treatment induced proline content elevation in the leaves (Fig. 2). The highest proline content was documented in CVS. JRC-532 and JRC-321 at 250 $\mathrm{mM} \mathrm{NaCl}$. The increase in proline content was positively correlated to the level of salt tolerance and it may be opined that proline was involved in salt tolerance in these jute cultivars in 

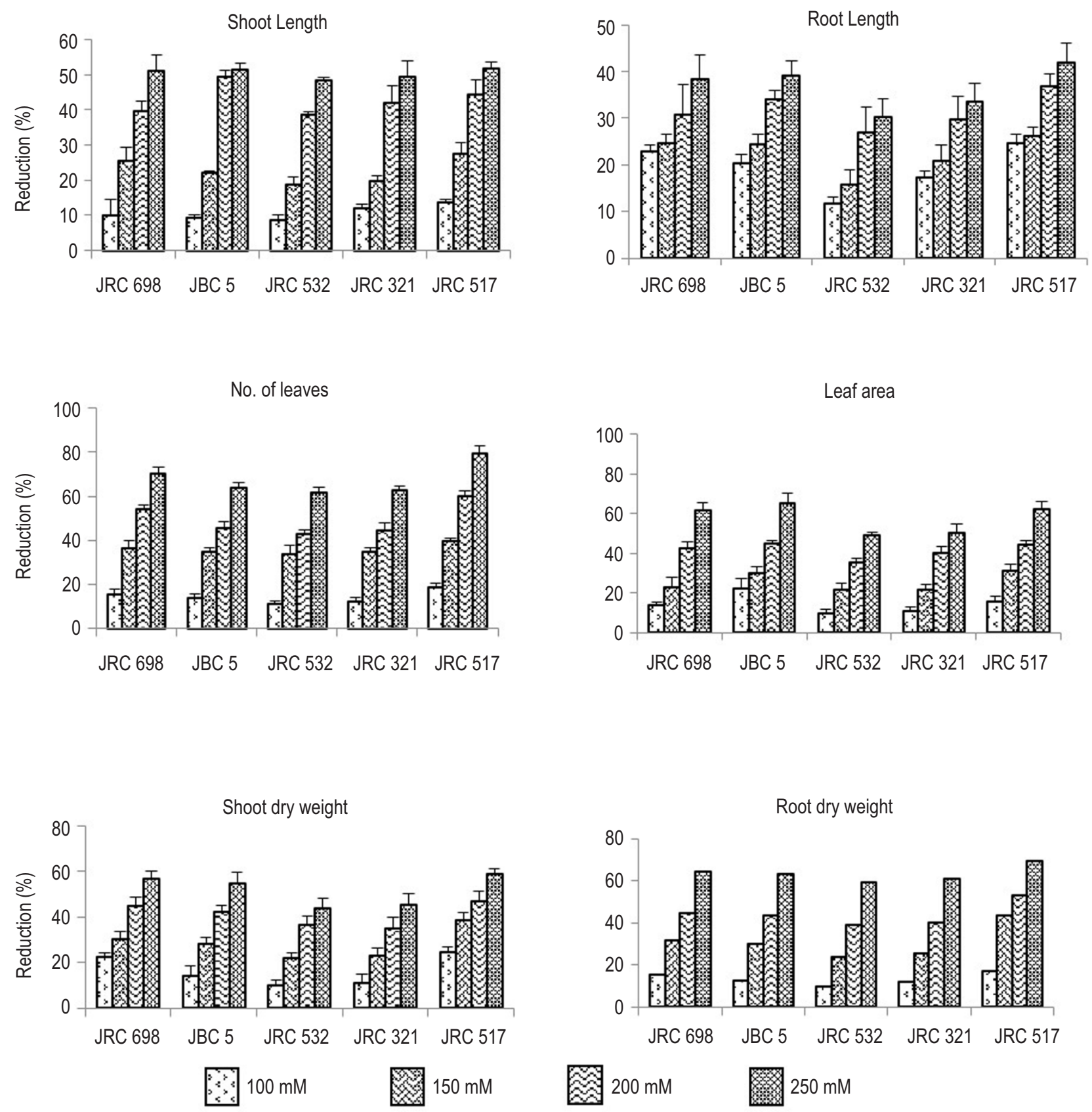

Fig. 1: Mean percentage of reduction ( \pm S.D) on different growth parameters of five jute cultivars owing to increasing levels of $\mathrm{NaCl}$ concentration.

contrast with the findings of Kahkahi et al. (2015). Salt stress gradually inhibited accumulation of protein in the leaves (Fig. 2). The highest protein content $\left(10 \mathrm{mg} \mathrm{ml}^{-1}\right)$ was accumulated in $\mathrm{cV}$. JRC-532 under control condition followed by cV. JRC-698 (9.9 mg $\mathrm{ml}^{-1}$ ). Inverse trend was observed in protein accumulation with increasing level of salt concentration and lowest protein content (4.6 $\mathrm{mg} \mathrm{m}^{-1}$ ) was recorded in $\mathrm{CV}$. JRC-698 at $250 \mathrm{mM} \mathrm{NaCl}$.
Similar inhibition of protein content under salt stress condition was acquainted in sorghum (Azooz et al., 2004). Analysis of variance revealed a significant effect of salinity $(P<0.05)$ on $\mathrm{Na}^{+}$ and $\mathrm{K}^{+}$ion accumulation in shoot and leaves. The presence of $\mathrm{NaCl}$ in the rooting medium despite induced an increase in $\mathrm{Na}^{+}$ concentration in shoots and leaves (Fig. 3) the $\mathrm{K}^{+}$content decreased with the treatments imposed. Similar results were 
Table 1: Chlorophyll content $\left(\mathrm{mg} \mathrm{g}^{-1}\right)$ of five jute cultivars in response to five levels of sodium chloride

\begin{tabular}{llll}
\hline Treatments & Chlorophylla & Chlorophyll b & Total Chlorophyll \\
\hline Cultivars & & & \\
JRC-698 & 1.81 & 0.57 & 2.39 \\
JBC-5 & 1.67 & 0.62 & 2.30 \\
JRC-532 & 2.08 & 0.67 & 2.75 \\
JRC-321 & 2.04 & 0.65 & 2.69 \\
JRC-517 & 1.65 & 0.49 & 2.15 \\
SEm \pm & 0.09 & 0.01 & 0.09 \\
C.D & 0.32 & 0.06 & 0.33 \\
NaCl concentrations & & & \\
$0 \mathrm{mM} \mathrm{NaCl}$ & 2.25 & 0.89 & 3.14 \\
$100 \mathrm{mM} \mathrm{NaCl}$ & 1.96 & 0.72 & 2.69 \\
$150 \mathrm{mM} \mathrm{NaCl}$ & 1.81 & 0.63 & 2.44 \\
$200 \mathrm{mM} \mathrm{NaCl}$ & 1.70 & 0.40 & 2.10 \\
$250 \mathrm{mM} \mathrm{NaCl}$ & 1.53 & 0.35 & 1.89 \\
SEm \pm & 0.03 & 0.02 & 0.04 \\
C.D & 0.11 & 0.06 & 0.11 \\
Interaction & $* *$ & $*$ & $* *$ \\
\hline
\end{tabular}

${ }^{* *}$ Significance at $p \leq 0.05$
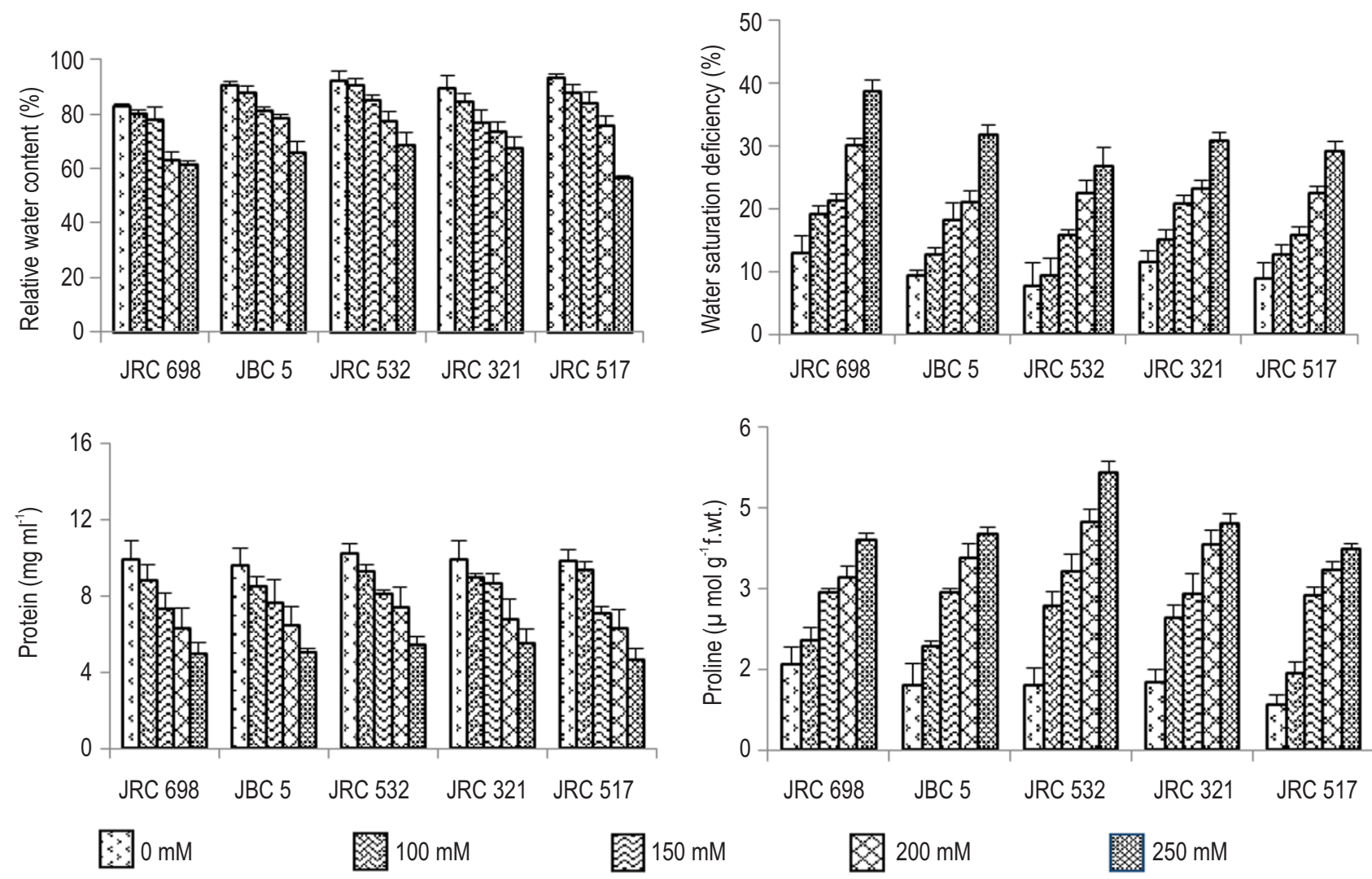

Fig. 2 : Mean ( \pm S.D) of relative water content of leaves, water saturation deficit, protein and proline content of five jute cultivars submitted to different levels of $\mathrm{NaCl}$. 

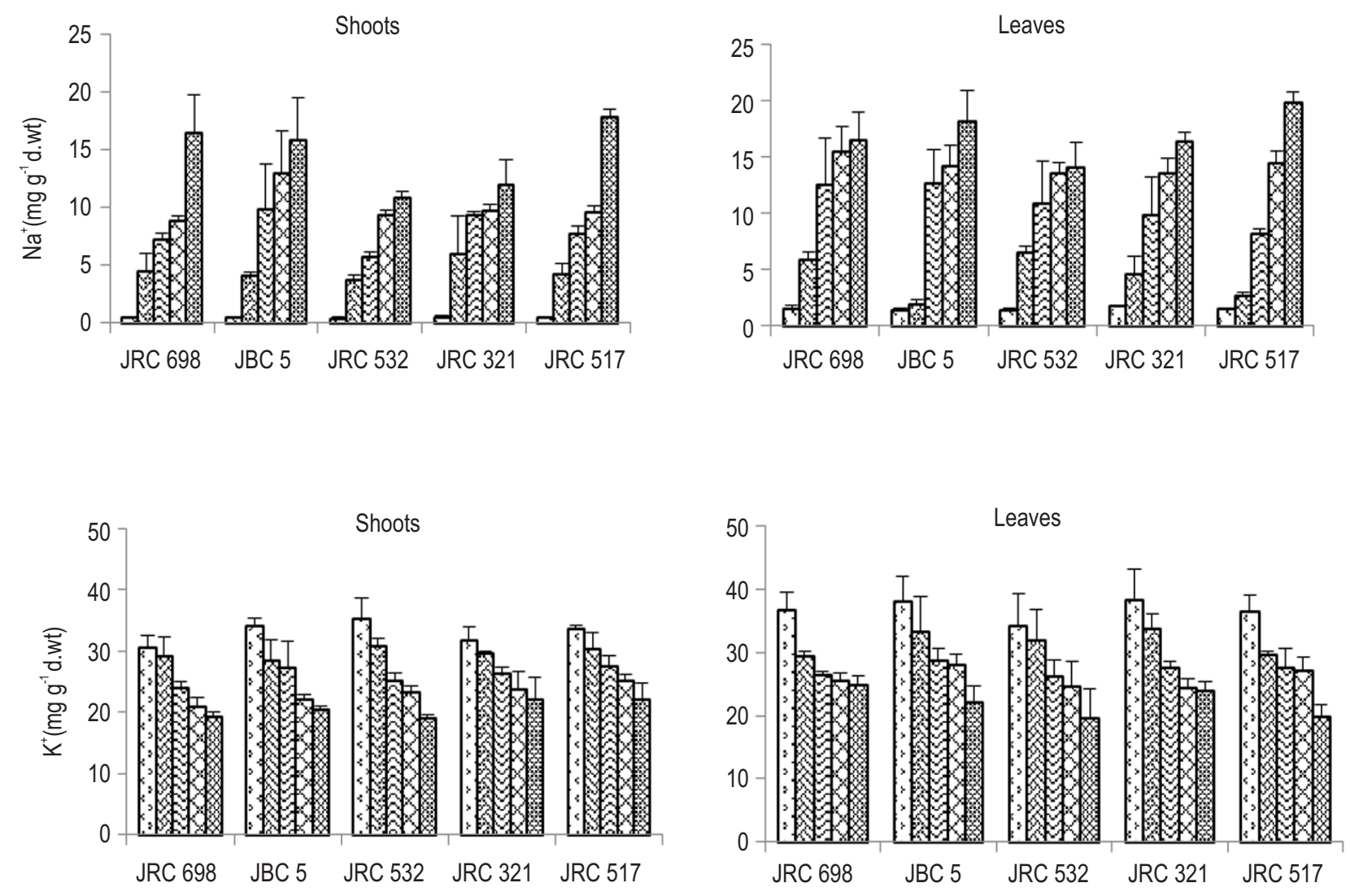

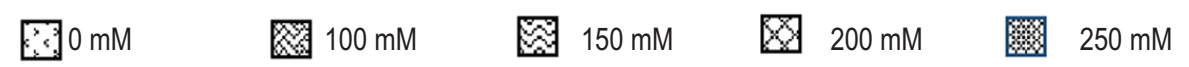

Fig. 3: Mean dry weight of $\mathrm{Na}^{+}$and $\mathrm{K}^{+}$content $\left(\mathrm{mg} \mathrm{g}^{-1}\right)$ in shoot and leaves of five jute cultivars after 20 days of treatment with different $\mathrm{NaCl}$ levels.

reported in other crops (Ghoulam et al., 2002; Hoque et al., 2015). Potassium content is often described as the quality element, especially more important for fibre quality. potassium ion concentration in the shoots and leaves of all tested cultivars significantly decreased in response to $\mathrm{NaCl}$ concentration and found higher in the control than treatments. The highest $\mathrm{K}^{+}$ion accumulation was recorded in leaves of cv. JRC-321 (38 $\mathrm{mg} \mathrm{g}^{-1}$ d.wt.) followed by JBC-5 under control condition. There was no significant difference in $\mathrm{Na}^{+}$ion accumulation among the cultivars.

The cv. JRC-532 accumulated less $\mathrm{Na}^{+}$ions in shoot (10.7 $\mathrm{mg} \mathrm{g}^{-1}$ d.wt.) and leaves (14.1 $\mathrm{mg} \mathrm{g}^{-1}$ d.wt.), in contrast to $\mathrm{CV}$. JRC517 , which accumulated highest $\mathrm{Na}^{+}$ions in the shoot $\left(18 \mathrm{mg} \mathrm{g}^{-1}\right.$ d.wt.) and leaves (20 mg g ${ }^{-1}$ d.wt.) at $250 \mathrm{mM} \mathrm{NaCl}$. This accumulation of salt ions could play a pivotal role in osmotic adjustment in salinity stressed jute plants. The presence of $\mathrm{NaCl}$ in the rooting medium caused a disturbance in membrane permeability expressed by an increase in solute leakage. Among the tested cvs., JRC-532 and JRC-321 outperformed salinity stress imposed and can be recommended for cultivation in coastal areas. The tested cultivars accumulated high concentration of $\mathrm{Na}^{+}$and $\mathrm{K}^{+}$in the leaves which is necessitated for osmotic adjustment in salinity stress. Pedigree information of these cultivars revealed that these cultivars might have derived salinity tolerance from indigenous type 'Hewti'. Hence, in future breeding programs for the development of salinity tolerant jute cultivar indigenous type 'Hewti' can be considered as salinity tolerance source. The results further revealed that both morphological and physiological parameters can be considered as screening criterion for assessing salinity tolerance in jute.

\section{Acknowledgment}

Authors are thankful to the Director ICAR-CRIJAF, Barrackpore for providing resources and facilities for conducting the experiment. 


\section{References}

Abass, S.M. and H.H. Latif: Germination and protein patterns of some genotypes of two species of jute as affected by $\mathrm{NaCl}$ stress. Pak. J. Biol. Sci., 8, 227-234 (2005).

Akram, M., M.Y. Ashraf, R. Ahmad, E.A. Waraich, J. lqbal and M. Mohsan: Screening for salt tolerance in maize (Zea mays L.) hybrids at an early seedling stage. Pak. J. Bot.,42, 141-154 (2010).

Ashraf, M.: Biotechnological approach of improving plant salt tolerance using antioxidants as markers. Biotechnol. Adv., 27, 84-93 (2009).

Azooz, M., M.A. Shaddad and A. Abdet Latef: The accumulation and compartmentation of proline in relation to salt tolerances of three sorghum cultivars. Indian J. Plant Physiol., 9, 1-8 (2004).

Bates, L.S., R.P. Waldron and I.D. Teare: Rapid determination of free proline for water stress studies. Plant Soil, 39, 205-208 (1973).

Chaudhuri, K. and M.A. Choudhuri: Effect of short term $\mathrm{NaCl}$ stress on water relations and gas exchange of two jute species. Biol. Plant., 40, 373-380 (1997).

Choudhary, S.B., H.K. Sharma, P.G. Karmakar, A.A. Kumar, A.R. Saha, P. Hazra and B.S. Mahapatra: Nutritional profile of cultivated and wild jute (Corchorus) species. Aust. J. Crop Sci., 13, 73-82 (2013).

Dansi, A., A. Adjatin, H. Adoukonou-Sagbadja, V. Falade, H. Yedomonhan, D. Odou and B. Dossou: Traditional leaf vegetable and their use in the benin republic. Genet. Resour. Crop Evol., 55 1239-1256 (2008).

Ghosh, R.K., T. Phumichai and T. Sreewongchai: Evolution of salt tolerances of jute genotypes in hydroponics using physiological parameters. Asian J. Plant Sci., 12, 149-158 (2013).

Ghoulam, C., A. Foursy and K. Fares: Effect of salt stress on growth, inorganic ions and proline accumulation in relation to osmotic adjustment in five sugar beet cultivars. Environ. Exper. Bot., 47, 39-50 (2002).

Hameed, M. and M. Ashraf: Physiological and biochemical adaptations of Cynodon dactylon (L.) Pers. from the salt range (Pakistan) to salinity stress. Flora, 203, 68-694 (2008).

Hiscox, J.D. and G.F. Israelstam: Amethod for extraction of chlorophyll from leaf tissue without maceration. Can. J. Bot., 57, 1332-1334 (1979).

Hongya, M., Y. Ruifang, W. Zhankui, Y. Tian, J. Yuying, G. Hanyan, W. Xiansheng and M. Hao: Screening of salinity tolerantjute (Corchorus capsularis and Corchorus olitorius) genotypes via phenotypic and physiology-assisted procedures. Pak. J. Bot., 43, 2655-2660 (2011).

Hoque, M. M. Ibne, Zheng Jun and W. Guoying: Evaluation of salinity tolerance in maize (Zea mays L.) genotypes at seedling stage. $J$. BioSci. Biotechnol., 4, 9-49 (2015).

Islam, M.T., M.B. Begum and M.O. Islam: Screening of jute mutants for salinity tolerance. Int. J. Sustain. Crop Prod., 6, 6-11 (2011).

Islam, S., S.A. Muhammad, S. Sazia, A.S. Abu, A. Maksudul, R. Shamim,
A. Rajib and K. Haseena: Improved salt tolerance of jute plants expressing the kat $\mathrm{E}$ gene from Escherichia coli. Turkish J. Biol., 37, 206-211 (2013)

Kahkahi, El.R., M. Mouhajir, S. Bachir, A. Lemrhari, R. Zouhair, M. Ait Chitt and R. Errakhi: Morphological and physiological analysis of salinity stress response of Carob (Ceratonia siliqua L.) in Morocco. Sci. Int., 3, 73-81 (2015).

Kingsbury, R.W. and E. Epstein: Selection for salt-resistant spring wheat. Crop Sci., 24, 310-315(1984)

Kotagiri, D. and V.C. Kolluru: Effect of salinity stress on the morphology and physiology of five different coleus species. Biomed. Pharmacol. J., 10, 1639-1649 (2017).

Lowry, O.L., N.J. Rosebrough, F. Lewis and R.J. Randall: Protein measurement with the folin phenol reagent. J. Biol. Chem., 193, 265-275(1951).

Ma, H., R. Yang, Z. Wang, T. Yu, Y. Jia, H. Gu, X. Wang and H. Ma: Screening of salinity tolerant jute (Corchorus capsularis and C.olitorius) genotypes via phenotypic and physiology-assisted procedures. Pak. J. Bot., 43, 2655-2660 (2011).

Mandal, A.K., R.C. Sharma, G. Singh and J.C. Dagar: Computerized data base on Salt affected soils in India. Technical Bulletin, Karnal (2010)

Munns, R. and A. Termaat: Whole-plant responses to salinity. Aust. J. Plant Physiol.,13, 143-160 (1986).

Munns, R. and M. Tester: Mechanisms of salinity tolerance. Annu. Rev. Plant Biol., 59, 651-681(2008).

Naik, M.R., M. Kumar, D. Barman, P.N. Meena, A. A. Kumar and D.K. Kundu: In vitro screening of white Jute (Corchorus capsularis L.) against salinity stress. J. Appl. Nat. Sci., 7, 344-347 (2015).

Odunnaike, J.O., A.A. Ajiboye and D.A. Agboola: Investigations on the effect of salinity stress on the seedling growth of Corchorus olitorius. Science Focus, 18, 21-30 (2013).

Saunders, M.: Recovery plan for the endangered native jute species, Corchorous cunninghamii F. Muell in Queensland (2001-2006) Environmental Protection Agency, Natural Heritage Trust, Australia (2001).

Smart, R.E. and G.E. Bingham: Rapid estimation of relative water content. Plant Physiol., 53, 258-260 (1974).

Steyn, N.P, J. Olivier, P. Winter, S. Burger and S. Nesamvuni: A survey of wild, green, leafy vegetables and their potential in combating micronutrient deficiencies in rural populations. S.A. J. Sci., 97, 276-279 (2001)

Weatherly, P.E. and R.O. Slatyer: Relationship between relative turgidity and diffusion pressure deficit. Nature,179, 1085-1086(1957).

Zhang, L., H. Ma, T. Chen, J. Pen, S. Yu and X. Zhao: Morphological and physiological responses of cotton (Gossypium hirsutum L.) plants to salinity. PLoS ONE, 9, e112807 (2014). 